\title{
Mothering Death: A Psychosocial Interpretation of Breast Cancer Biography
}

\author{
Birgitta Haga Gripsrud ${ }^{1}$ \\ ${ }^{I}$ Department of Caring and Ethics, Faculty of Health Sciences, University of Stavanger, Norway
}

$\mathbf{I}_{\mathrm{n}}$

this article I take as my point of departure a puzzle presented by a woman who had an apparently 'bizarre' reaction to a breast cancer diagnosis. In the clinic, she had exclaimed: "I would rather die than lose the breast!". My aim is to unpack layers in this woman's embodied and enculturated experience, with a view towards developing a psychosocial interpretation of breast cancer biography. The single case on which the present study is based, was extracted from a larger longitudinal data set which allowed me to follow 'Ella's' transition from diagnosis to survivorship. I relied on five sources of data to unfold the case: two participant-generated texts (expressive writing and a Breast Biography), two interviews, and my own field notes. The two texts that Ella wrote provided a participant-led frame for depth-hermeneutic group interpretation sessions, the first of which, synergistically, produced a scenic voicing of latent content in the sub-text of Ella's expressive writing: the fantasy of mothering death. This subsequently became a lead for my further interpretation of the case, and for methodological reflections on the value of shared thinking in qualitative data interpretation. Crucially, and with some bearing on the current healthcare context, this interpretive study sheds light on what goes on beneath the surface of an apparently 'irrational' and 'recalcitrant' patient, evidenced by Ella's entry into what I call a 'vortex of suffering'. Findings point towards her suffering as an expression of a psychosocial reality, against the backdrop of hope and ideals contained within a psychosocial imaginary that revolves around biomedical cure and reparation.

Keywords: breast cancer biography; the breast; psychosocial studies; depth-hermeneutics; vortex of suffering; psychosocial reality

"The experience of fragmentation which traumatic suffering entails resists any approach which assumes that experience can be mastered and known through rational discourse."

(Levine, 2009, p. 17)

\section{Introduction}

This article takes as its point of departure a puzzle presented by a woman who had an apparently 'bizarre' reaction to a breast cancer diagnosis. In order to provide an entry for engaged readership in this special issue on suffering in contemporary society, let me start with a brief vignette of how I was first introduced to this woman, whom I will call 'Ella':

While enrolling participants for research on women's experiences of breast cancer, I received a phone call from a clinician responsible for 
approaching potential participants. He told me that his colleagues had had an unusual consultation in the clinic that day with a recently diagnosed breast cancer patient, a Norwegian woman in her fifties who, at one point, exclaimed to her doctor, "I would rather die than lose my breast!" The clinicians were baffled by this dramatic statement. Despite their many years of accumulated professional experience, this patient's reaction was simply unprecedented. For me, there was no doubt that this could be an important participant to enrol, but I wondered if it was right to do so if she was in a state of high distress. Through off-and-on contact with her over several weeks, this question lingered on. In the end, Ella agreed to participate in the study. For a long time, I kept ruminating on her statement that she would rather die than lose her breast. Whereas other participants had spoken of how, in various mournful ways, they tried to come to terms with letting go of the breast in order to save their life, Ella presented a mystifying reversal.

My aim is to unpack layers in this woman's embodied and enculturated experience, with a view towards developing a psychosocial interpretation of breast cancer biography. To achieve this, I have analysed meanings derived both from the manifest text and the latent sub-text (Gullestad \& Killingmo, 2013) contained within Ella's written illness narratives. I understand the sub-text psychoanalytically, as being motivated by (partly) unconscious desires and fantasies belonging to a psychical reality - an autonomous order that exists beyond (but not separated from) material reality, entailing "everything in the psyche that takes on the force of reality for the subject" (Laplanche \& Pontalis, 1973, p. 363). My understanding is also informed by a psychosocial studies approach that is capable of holding together "an understanding of the workings of the psyche and the social without reducing one to the other" (Hollway, 2009, p. 461). In this sense, a more accurate conceptualisation of my object of inquiry would be to unpack layers in the psychosocial reality of Ella' breast cancer experience, a claim that may become more evident through what follows. 


\section{Background}

Kleinmann states that "Illness idioms crystallize out of the dynamic dialectic between bodily processes and cultural categories, between experience and meaning" (1988, p. 14). This is evidently so with breast cancer, an illness that, since the 1970s, has generated a substantial field of cultural-biographical meaning-making (DeShazer, 2013; Gripsrud, 2008). In my previous research, I found that women's narratives of breast cancer - somewhat paradoxically, in that they are articulations emerging from a loss of the breast - yield rich grounds for exploring meanings of the breast in embodied experience (Gripsrud, 2006, 2008). This subsequently led me into practice-near and experience-near research (Froggett \& Briggs, 2012) in two hospitals, in collaboration with breast cancer specialists who are frequently and painfully confronted with complexity in women's breast-loss experiences (Gripsrud et al., 2016; Gripsrud, Søiland, \& Lode, 2014; Solbrække, Søiland, Lode, \& Gripsrud, 2017).

The editors of this special issue bring our attention to the irrefutable ontological dimension of suffering. Cassel (2004) has similarly underscored suffering as a salient problem in medicine, the recognition and relief of which indicate the adequacy of the care and treatment provided. Having co-created data with breast cancer patients over a course of three years, I can attest to the feeling identified by Rodin and Zimmermann (2008, p. 182) of being "drawn into their emotional world because of the profoundly reverberating existential issues" they face due to a serious and life-threatening illness. This was, of course, related to my experience of witnessing and recognising participants' suffering, which manifested in a range of modalities across the sample (Gripsrud et al., 2016; Gripsrud et al., 2014; Solbrække et al., 2017) and has been identified in previous studies of women's breast cancer experience (Arman \& Rehnsfeldt, 2003; Langellier \& Sullivan, 1998). 
Forty years ago the poet Audre Lorde wrote, based on her own experience, that "Each woman responds to the crisis that breast cancer brings to her life out of a whole pattern, which is the design of who she is and how her life has been lived" (Lorde, 1980, p.1). Since then, a considerable body of research has explored women's experiences of breast cancer from psychological, phenomenological, and constructivist perspectives (Arroyo \& Lopez, 2011; Cheng et al., 2018; de Boer, van der Hulst, \& Slatman, 2015; Greco, 2015). But few studies have adequately addressed the breast cancer crisis as it relates to the "whole pattern" of a woman's subjectivity and biography, which, in my mind, merits a psychosocial orientation. A key concern for me is how we may adequately study experience, which is also subject to a high degree of enculturation. The embodied breast is a case in point, carrying deep-rooted sociocultural meanings related to life and to death, corresponding with its role in sexuality and breastfeeding and its susceptibility to cancer (Gripsrud, 2008). Adding to this "meaning knot" is the aesthetic investments of many societies in the breast as a symbol par excellence of femininity (Yalom, 1998), which may complicate women's embodied experience and, indeed, even turn the breast into a "defended object" that is difficult to relate discursively (Gripsrud et al., 2018).

\section{Methodological Approach, Design and Research Methods}

\section{A Psychosocial Approach to Illness Narratives}

The present study is informed by Psychosocial Studies, an emergent field of transdisciplinary inquiry that draws on and challenges established disciplines in order to develop new understanding of the interrelationships between sociocultural and psychological meaning. According to Stenner (2014, p. 206), this is because:

"questions of psychology can be very poorly posed when abstracted from their cultural, societal and historical settings, and likewise, because these settings are poorly understood in abstraction from the living, experiencing human beings whose actions make their reproduction and transformation possible. Ultimately this is because no clear distinction can finally be drawn between what we all too crudely call the 'inner world' and the 'outer world"'. 
Hence, studies of the psychosocial "take subjectivity seriously as an aspect of experience that cannot be reduced to discursive practices, even if those practices structure and pattern it" (Stenner, 2014, p. 206) - and, by implication, take seriously "the wish to focus on subjectivity as the total, substantive, acting, thinking and feeling, embodied, relational being, or [...] 'the becoming of being"” (Hollway, 2015: 21).

According to Hollway and Jefferson (2001, p. 105), "understanding of meaning in context has been at the heart of the development of narrative research", as evidenced in the many approaches scholars use to research a person's life story. However, what characterises and sets a psychosocial approach to narrative inquiry aside is a critique of the often implicit but naïve notion of the storyteller as a "unitary rational subject" (Hollway \& Jefferson, 2001, p. 106), "telling it like it is". A key concept in psychosocial research is the defended subject, which refers to the psychoanalytic proposition that "anxiety is inherent in the human condition, specifically that threats to the self, create anxiety. Defences against such anxiety are mobilised at a largely unconscious level [and are] a significant influence on people's actions, lives and relations" (Hollway \& Jefferson, 2001, p. 107). Further to this, Hollway (2009, pp. 461-462) emphasises how such psychoanalytically informed narrative research should "focus on the experiences of subjects who suffer $[\ldots]$ in the particularities of the settings, past, present and anticipated future, as people engage with and make meaning out of their situations and actions". In response to this, a nascent strand of psychosocial research on cancer narratives is emerging (see e.g. Aydin, Gulluoglu, \& Kuscu, 2012; Larsen, 2017), to which the present study is a new addition.

\section{Design: A Single Case Study}

Ella's case is extracted from a larger longitudinal data set (for details on the larger project, see Gripsrud et al., 2016; Gripsrud et al., 2014). Such single case studies and "thinking in cases" are foundational to psychoanalysis (Forrester, 2017), and a valued mode of inquiry in Cultural Studies (Gray, 2003) and Psychosocial Studies (Ramvi, 2015) because they allow for the study of particularity and complexity within a bounded entity (Stake, 1995). Sometimes, selecting a case is not really a "choice" at all; rather, it is "a given", as the researcher feels "obliged to take it as an object of study" - as was my experience with Ella, who offered me the opportunity to develop "an intrinsic case study" (Stake, 1995, pp. 3-4). In pragmatic and ethical terms, my obligation as a researcher has thus been "to understand this one case" (Stake 1995), because 
"cases matter in their own right" (Rustin, 2019, p. 97), and offer a means to explore a typology that lies between the particular and the general (Wengraf, 2001).

\section{Main Methods for Data Creation}

The primary material for the case is two written texts, which provide a participant-led frame for interpretation. Data were collected at two time points in Ella's breast cancer trajectory: shortly after diagnosis and primary surgery (T1) and one year later (T2), as she transitioned into survivorship. At $\mathrm{T} 1$, she was invited to engage in a form of expressive writing (EW) (Pennebaker, 1997) that encouraged free associations (Lothane, 2018) on emotional aspects of breast cancer. This premised on the understanding that breast cancer involves a distressing emotional experience that may be ameliorated by being expressed and symbolised (Gripsrud et al., 2016; Gripsrud et al., 2014). At T2, Ella was invited to write a Breast Biography - a new method for meaning-making on women's embodied experiences of breast cancer, eliciting biographical narration (Wengraf, 2001) of past, present, and anticipated future experience. The Breast Biography $(\mathrm{BB})$ is my own design, presented here for the first time (see Figure 1).

\section{Your Breast Biography}

Imagine that your breasts have a life-story of their own, intertwining with your personal biography. We invite you to write your breast biography from the beginning to where you are in life now, perhaps even into the future. The reason for this is that we would like to learn more about what your breasts have meant to you in the past, and what they mean to you now after breast cancer and the treatments you have gone through. Maybe this would be easier to write about than to talk about?

Suggested writing cues:

Tell the story of your breasts. Can you remember when you were a girl without breasts? How have your breasts journeyed, from puberty to adult life? Which thoughts and feelings do you associate with, for example breasts and womanhood, breastfeeding or not breastfeeding (your own or that of others), motherliness, loving relationships, sexuality? What about the look of the breasts - your own view and the views of others, before and now? Can you recall experiencing feelings in your breasts? Or any other breast-related experiences that you remember? How does your breast biography end: where are you today?

There is no wrong way to solve this task. If you get stuck, you can write your innermost thoughts and feelings about whatever is most pressing in your life right now.

You decide how much time you want to spend on this writing task. You could aim for $1 / 2-1$ page. If you feel like writing more, that's fine too. You can divide the writing into chunks and spread it out or write it all in one go. You can write quite freely and really express yourself. Spelling and grammar are not important here. Just write! If you feel like writing keywords, a poem or a diary instead of a biographical text, that's ok too. This is your text and you decide what your breast story should look like.

Figure 1: An invitation to write a Breast Biography. Design: Birgitta Haga Gripsrud 
Ella's writings were followed by a semi-structured interview at $\mathrm{T} 1$ and a narrative interview at T2. The interviews took place after the writing and lasted in excess of 90 minutes. I did not read Ella's texts before the interviews. In addition to the interviews, the EW and BB, I have also relied on field notes to access and develop my researcher subjectivity as an instrument of knowledge (Hollway, 2015) and to enrich my presentation of the case.

Overall, my approach to data creation in this study evokes a methods bricolage and “creating structures by means of events" (Lévi-Strauss, 1966, p. 22), relying on the elements at hand. For example, the emphasis on participant writing emerged from my experience as a teacher of creative writing. Although the present study cannot be said to adhere to a fully metabolised psychosocial methodology (see e.g. Gripsrud, Ramvi, Froggett, Hellstrand, \& Manley, 2018; Ramvi et al., 2019), it is my view that the bricolage generated a rich-enough material for developing "thick description and interpretation" (Geertz, 1973) of the single case, which have been augmented by applying a psychosocial optic. Further to this, the bricolage also offered the benefits of "technique triangulation" (Hammersley \& Atkinson, 1983) between interviews and writings, and indeed for verification of a key finding in the interpretation, as will become apparent. 


\section{A Psychosocial Interpretive Approach}

Conducting research "to bring the unconscious within the domain of consciousness" has methodological implications (Rustin, 2019: 269), which, in this study, are most palpable in the depth-hermeneutic approach to group interpretation of the data (Gripsrud, Mellon, \& Ramvi, 2018; Hollway \& Volmerg, 2010) in a tradition, which draws on Alfred Lorenzer's psychoanalytically informed cultural analysis. This mode of group interpretation concerns "letting the data speak to us" as researchers (Hollway \& Froggett, 2012) - and paying attention to how "a text works on or plays with a reader's experience (unconscious or otherwise)", provoking emotional reactions through an autonomous level of meaning that is psychosocially constituted (Bereswill, Morgenroth, \& Redman, 2010, p. 223). In this sense, depthhermeneutics "aim[s] to go beyond the immediate level of meaning in a text by investigating its latent "schemes of life that have been excluded from societal consensus"” (Krüger cited in Gripsrud, Mellon, et al., 2018, p. 641), "seeking to 're-integrate' human experience as embodied, individual, unconscious, relational and social" (Gripsrud, Mellon, et al., 2018, p. 641). By engaging in a shared analysis of short data extracts, it is possible to bring to "the surface obscured content emerging reflexively in the group's thoughts, feelings and fantasies about the text” (Gripsrud et al., 2018), in an “"intermediate' area lying 'in-between' reality and imagination”, and 'inner' and 'outer' worlds (Hollway \& Froggett, 2012, para 1).

Ella's two texts $(\mathrm{EW}+\mathrm{BB})$ were introduced to an interpretation group of five researchers with diverse disciplinary backgrounds, nationalities, genders, and ages. In order to make the data accessible to the interpretation group, I translated Ella's texts from Norwegian to English, seeking to retain her idiosyncratic linguistic expression. The texts were presented to the group unabridged. As the researcher bringing in the data, I opted not to offer a pretext, and I remained silent during the interpretation; however, I did take notes throughout the session. I kept silent in order to allow the group's associations and "sociological imagination" (Wengraf, 2001) to develop beyond the reflexive frame of my preunderstanding of the study and this particular case. As you recall, my interest was to explore the sub-text (Gullestad \& Killingmo, 2013) and divine what lay "beneath the surface" (Clarke \& Hoggett, 2009) of Ella's statement that she would "rather die than lose the breast". In writing up the case, I have subsequently used interview data $(\mathrm{T} 1+\mathrm{T} 2)$ and field notes to supplement the interpretation. Following Geertz (1973), applications of theory should contribute to making "thick description", and to 'generalising' within the case, and this is what I will pursue in the findings and discussion. 


\section{Ethics}

Formal approval was granted by the Regional Committee for Medical and Health Research Ethics (REK Vest 2012/926). Ella was fully informed several times before consenting to take part in the study, including of her right to withdraw from the research at any time. "Ella" is a fictitious name, and details have been altered to protect her anonymity. Beyond formal research ethics, there exists a challenging landscape of reflexive research ethics. For one, the psychosocial proposition of the defended subject has repercussions for investigations of suffering or any other frightening, painful, or taboo issue, with breast cancer being an illness experience likely to encompass all of these. As a researcher in this field, therefore, my capacity for emotional containment (Hollway, 2008) - while dealing with my own defended subjectivity and identifications (Ramvi, 2015) - were preconditions for establishing a working and ethically sound alliance with Ella. In this sense, the impact of intersubjectivity in studies of the psychosocial is considered not as a "pollutant" but as the constitutive fact of data creation (Wengraf, 2001).

During enrolment, I worried that Ella may be too distressed to take part in the study. However, she stayed in touch with me for several weeks, and together we carefully negotiated her contribution to the study, ensuring she was the one setting the premises. Upon meeting her at home for the first interview, I was highly sensitive to Ella's state of mind. My immediate impression was that she was in a reactive state; from my first question onwards, tears were streaming down her face. She kept a tissue pressed to her face throughout the interview, occasionally pausing to blow her nose with great vigour, as if she were expunging the mucous from the soles of her feet. Towards the end, both humour and anger emerged allowing for other emotional expressions than sadness. Throughout the interview, Ella was intensely preoccupied with the threat of the losses she associated with cancer treatment (e.g. of breast, hair, teeth, vitality, joy). However, her state of anxiety and vulnerability seemed counter-balanced by her robust, direct, and forceful personality. A sense of trust between the two of us was established early on. To illustrate:

At one point in the first interview, Ella got up, pulled up her sweater, and invited me to look at her breasts. They were beautiful and full, and in their pointy youthfulness reminded me of my own breasts before I became pregnant and then a mother. Did I touch her new nipple-less reconstructed breast shape? Years after, I can't recall for sure. 
Reminiscing, I feel the impulse to touch her breast and that by touching it I could somehow sanctify it for her and make things better. I must have stopped myself from actually doing so because it would have been transgressive of my 'mandate', but such was the nature of our relation that I can now easily imagine reaching my hand out to touch her strange new breast.

(Observation from $\mathrm{T} 1$ and retrospective reflection, field notes)

Similarly, at the T2 interview, Ella invited me to feel her newly emerging post-chemo hair, which she said was “soft - like a baby's". Ultimately, the interviews' atmosphere, characterised by intimacy, containment, and recognition (Hollway, 2008), reassured me of the ethical soundness of our co-creation. I invited Ella to contact me after the interviews, should she need support; however, she never took up this offer.

\section{Findings}

Ella was an unusual breast cancer patient and a divergent research participant. To help me think about the puzzles in her case, I decided to explore her two narrative texts $(E W+B B)$ in two depth-hermeneutic group interpretation sessions. The first session was on Ella's EW (4 pages), completed two weeks after mastectomy and immediate reconstructive surgery (T1). Below are two excerpts, indicating Ella's state of mind after the diagnosis, the first of which was her opening passage:

"The first thing I thought when I found a lump in my left breast as I was soaping up [in the shower] was 'fuck, now it won't be long before I die'. 53 years old, this was earlier than I had thought. I told my husband. The weekend I discovered that lump is the weirdest and at the same time the saddest weekend I have had in all my life. In my thoughts I found a new wife for my husband. The waiting time for answers to all $\mathrm{X}$-rays and tissue samples has been a hell, very hard to gather [my] thoughts about anything other than that I will soon die or that the life that's awaiting me will contain very little joy and happy moments" (Ella, EW/T1, first paragraph). 
"Since I found the lump in my breast and up until now, I have thought very much about whether I want to live if I end up getting late effects from the treatment I have to undergo to get cured from breast cancer. What good does it do if I recover from breast cancer but get sick from the treatment that is offered? I can feel a sense of panic with regard to chemotherapy and radiation for that reason" (Ella, EW/T1).

Having read the whole text aloud, the first responses in the group were that this was "heavy stuff" and "chaotic". Ella was facing "many battles at the same time". In the strong opening passage, Ella had thought "this is it", as she found the lump in her breast. The group noted the sentences, "I found a new wife for my husband", and "He will then not have to have a sick wife"; it was as if her life had stopped, and she was alone in dealing with her breast cancer Ella is the one who must walk the line. It was hypothesised that Ella was melancholic, perhaps related to bodily changes and loss of attractiveness. Could this explain her wanting to substitute herself by finding a new wife for her husband? He should continue having a good life with a new woman instead of living with her, the "damaged Ella". The group reflected that these could also be realistic thoughts, as some husbands do leave their wives when they get cancer. A counterhypothesis was raised: Ella was not in a melancholic state; rather, she presented as being active and in control. At this stage, one member of the group interrupted, feeling irritated by the "unbearable interpretation", asking why the group was not engaging with the text's desperate sense of isolation: Ella felt that she deserved to die, that she did not deserve to be loved or held by love, even in this dire situation. This was a moment of emotional friction, which fuelled further interpretation.

I now move away from the first responses of the group to the first interview I did with Ella 4-5 weeks after her surgery. She did indeed end up getting "sick from the treatment", as she feared in her EW, and our first appointment was cancelled because she was ill. In total, she was admitted to hospital on five occasions during chemotherapy. In the interview, Ella said that she had previously had a good life. She had been doing fine: healthy, strong, and feeling well, with few worries. She took life for granted and would make plans for years ahead - setting goals for the future. She loved her work as a helping professional. The diagnosis came as a complete shock: she found a lump in her breast, went to have it examined, and was diagnosed with pre-stage breast cancer. Shortly before surgery, however, Ella was told it was a more invasive cancer. With a more severe prognosis, suddenly life became very serious, even though 
she still remained within the curative medical spectrum. She feared there would not be much left of her by the time she finished her oncological treatment. Ella said she was "still sort of in a place where I'm ambivalent in relation to life". Both in the EW and in this interview, she stated that she had considered dying rather than enduring chemotherapy and radiation. However, Ella did not mention to me the thought that she would rather die than lose the breast, and her statement in the clinic therefore remained a mystery. In the end, it was her husband who changed her mind about complying with the treatment plan - he had told her he wanted to have her around for as long as possible, thereby refuting Ella's thoughts of finding him a new wife.

In the interview, Ella talked about an embarrassingly increased sense of vanity, despising the fact that appearance had suddenly become so important to her. The idea that others should see her as a cancer patient, without hair, even on the oncology ward, was simply unbearable. She therefore stayed home as much as possible, and during admissions to the hospital, preferred for the door to her room to remain closed. What did Ella's intense fear of exposure concern? To try to answer this, I must take you back into the interpretation group, where her writing was still under scrutiny. Below are two salient extracts:

"What wrong have I done to deserve getting cancer and sequels from the cancer treatment. I myself think that I am mostly kind so I can't quite get to grips with it" (Ella, EW/T1).

"I'm ashamed to have got breast cancer, therefore I don't tell others about it, I'm afraid they'll think 'what wrong has she done to have got breast cancer"” (Ella, EW/T1).

The group was puzzled by Ella's guilt and shame, as breast cancer is in no way self-afflicted. Pursuing this puzzle as far as possible in this first session, it was noted that one of Ella's battles was how she would deal with the cancer, and another was how to not be excluded from society. She was deeply concerned with other people's views of her, and that they would judge her because of the cancer; hence, she felt that she must not tell people about it or show herself as having it. With her question, "what wrong have I done?", she was being hard on herself, despite being in a vulnerable or at least objectively undeserved situation. The group reflected on this as a 'societal symptom' in that it is not easy to be sick in contemporary society and that it is 
difficult to speak about death and serious illness. Was Ella not allowed to feel sad or identify as a victim? Did she feel obliged to be tough and strong, even in such a crisis?

As the first interpretation session came towards the end, a chain of dark reasoning arose, presented by one of the group members in a highly scenic mode (Hollway \& Froggett, 2012), 'giving voice' to Ella:

"The body betrayed me when I got cancer. I took care of my body and now it has betrayed me. When you are pregnant, the body has a will of its own. But with cancer, it is not a foetus growing inside but death is growing, uncontrollably. I never became a good mother; I have to be ashamed. What I am bearing is the devil. With cancer, I can become the mother of my own death."

(field notes from the interpretation session, my emphasis in bold)

I was astonished, feeling the hairs at the back of my neck rising. Because I realised that, uncannily, this group member's scenic voicing had articulated latent content within the subtext of Ella's first written narrative at T1 that only I knew about. Recall that I had given no pretext about Ella before the interpretation group engaged with her EW text; the group knew nothing about her family status.

It took time for Ella to be able to articulate this painful experience in writing, one year after diagnosis:

"I don't have children. When I was in my twenties, I became pregnant. At that time, I chose to have an abortion for several reasons, one being because I got pregnant by the wrong man and because I was studying at the time. When I was in chemotherapy, I thought that God punished me by letting me get breast cancer because I had had an abortion. And still I am not sure whether the reason why I got breast cancer is because

\footnotetext{
${ }^{1}$ Professor Inger Marie Lid brought to my attention that 'mothering death' evokes a biblical passage in Jeremiah 20:17-18: "Because he slew me not from the womb; or that my mother might have been my grave, and her womb to be always great with me. Wherefore came I forth out of the womb to see labour and sorrow, that my days should be consumed with shame?"
} 
I have not breastfed/used my breasts for their intended purpose" (Ella, $\mathrm{BB} / \mathrm{T} 2)$.

In the second interpretation group session, the focus was on this BB text. Someone noted its stylistic aspect as a performative narrative, from which Ella emerged as an athletic figure, climbing the hills, thinking 'I am tough, I did it myself' - projecting the image of a strong and independent woman. The group noted that Ella used to be, and still is, an attractive woman and that this means a lot to her: she likes herself and her body, and is idealising natural beauty. She does not wear makeup or even a bra - she resists such modifications quite strongly. From the text, the group gathered that Ella's breasts had been seductive to her lovers, who admired their firm and youthful qualities, providing her with affirmation as a woman. But then she lost a cherished breast in an awful operation. The reconstruction conformed to a type of feminine cosmeticising that she despised before cancer. The group noted that Ella must have felt breast cancer as a menace to her natural beauty, vitality, and being. However, writing one year after the diagnosis, Ella revealed that she was glad to be alive. Sexuality still meant a lot to her, but in new ways. At an emotional level, the group noted that the BB contained more love than Ella's EW, representing coming-to-terms with the illness. This was also recognised by the group as identity work, where Ella had shifted her emotional investment from 'classic feminine narcissism' (self-love through the gaze of the other) to something less externalised.

Even so, the group continued to be puzzled by Ella's guilt and shame about having breast cancer. The four sources of data that Ella contributed to have allowed me to interpret this puzzle further. In her BB, Ella refers to the diagnosis as a "tremendously traumatic experience". In the follow-up interview, Ella told me that throughout the period after diagnosis, she had felt persecuted by the idea that she was to blame for the cancer, that she had done something wrong. She said she had felt "screwed up mentally" and had experienced suicidal thoughts - "Just come and take me" were her words, hinting at an omnipotent God. The abortion was "a somewhat easy choice" she had previously made because circumstances were not good for having a child. But when she got diagnosed, it felt to her as if God had inflicted breast cancer on her vindictively. At T1, Ella's sense was that because she was bald from chemo, everyone could see that she had cancer because she was a bad person. Over time and with the experience that things went well after all, she was able to loosen the grip of this punishing fantasy and place it within the realm of chaos triggered by her diagnosis. One year after diagnosis, Ella wrote: "today I know that this [fantasy] is not true" (BB, T2). However, total absolution had not been 
granted to her. In her BB, Ella transformed the fantasy into a more 'scientifically credible' derivative: that she got breast cancer because she had never breastfed a baby. That breastfeeding protects women from developing breast cancer was something she knew about. Could it be that Ella's sense of shame and culpability concerned not only the abortion, but also feelings associated with sexuality, since she so emphatically writes that she "has not used the breasts for their true purpose" (that is mothering/breastfeeding)?

Ella's pride in her breasts was largely related to her lovers' appreciation. In the interpretation group, there were speculations as to whether Ella's guilt and shame concerned a deeper experience of some unrealised potential in her life. When breast cancer invaded her strong and vibrant female body, long-forgotten concerns were re-actualised, including unpredictable fertility, and perhaps unarticulated ambivalences or even longings related to pregnancy, maternity, and breastfeeding as missed opportunities. These existential concerns may have been resonant in Ella's pull towards self-eradication after diagnosis, as well as in her intense fear of experiencing cancer-related loss (e.g., of health, self, relations, breast, hair, humour, joy, work). Evidence in support of this interpretation emerged in the one-year followup interview, when Ella referred to a conversation with a friend who had also had breast cancer. This friend said that she never felt that she could choose whether or not to have cancer treatment because she wanted to live. Ella then told her friend, "No, but then it's not your choice, then there are others who have chosen for you." Ella continued referring to this conversation, stating, "But she [the friend] had children. Perhaps that's different." Here, Ella made an associative leap to motherhood when trying to understand her friend's motivation for complying with treatment. It made me wonder about what Ella was not saying: that a woman who is a mother has something to live for, but a woman without children can just choose to die.

One year after, Ella was aware that the divine punishment she imagined in relation to the abortion was absurd; she thought it was "crazy" in many ways. But nevertheless, she had also experienced it as real and painful. The breast cancer and the "poisonous" chemotherapy specifically had, as she said, triggered "old crap".

We recall the remarkable story from the clinic, where Ella had said she would rather die than lose her breast. At T1, Ella made no mention of it in the interview. The statement in the clinic therefore remained a mystery until one year later, at the very end of the follow-up interview, when she spontaneously recalled the situation. The prelude was that I asked her about the surgical decision-making process. Ella then said she had insisted on choosing what happened to her breast, and recounted the following: 
"Well, I was there on a Thursday, I was diagnosed on a Thursday and I was told ... I got a date, a note in my hand with a date, 'look here', a nurse reached out and gave me a note with a date and time on, and it [the operation] was on the Tuesday [the following week]. And that's when they would take away my breast. And then I said 'no, no', I wasn't interested in that note, that date. It's crazy. [...]

- 'But you have to take away the breast, we must remove it,' said the doctor.

- 'But I don't have to ... I do not have to ... [do] absolutely any... thing.'

- 'But you do have to do it, you can die if you don't remove it.'

- 'Yeah, but I could just die, then?'

- 'Yeah, but you can't do that?'

- 'Yes, I could do that. It is of course I who decide that.

And if that's what I want to choose, to die.'

- 'Yeah, but you can't do that?!'

- 'Yes, I can."'

What Ella recounted to me was a dialogue of shock and resistance, where she and a surgeon went head-to-head in a veritable power battle between her claim to self-determination and the doctor's wish to intervene in her body, take the breast and thereby preserve her life. Reconstruction was the subsequent trade-off from this consultation, ensuring that Ella did not transgress the timeline in her standardised trajectory, by continuing to be a 'recalcitrant' and therefore resource-demanding patient. In hindsight, Ella credited two other doctors with changing her desperate outlook: a surgeon who, after her operation, reassured her that she was now cancer free, and an oncologist who supported her decision-making on chemo and radiation by saying "you can choose ... you don't have to go through this if you don't want to". The oncologist's capacity to humour Ella's 'irrational' ideas of refusing treatment, reveals how "healing is also a mode of being present, of attending to the suffering, of letting it find its form" (Levy, 2009, p. 27). This encounter may indeed have been key to resolving the situation, as it left Ella assured that " $I$ am the one who made the choice". 
I now wish to discuss some intrinsic and extrinsic aspects of Ella's case, as well as methodological implications emerging from the scenic voicing of mothering death by the interpretation group.

\section{Discussion}

I have arrived at a point where the case's puzzling aspects are becoming more cogent, including Ella's insistence that she would rather die than lose her breast. The interpretation group established a breakthrough on Ella's sub-text: "With cancer, I can become the mother of my own death". In doing so, the group also gave voice to, avant coup, Ella's “crazy" punishment fantasy, in which a past experience of an aborted pregnancy became reanimated by the recent trauma of her breast cancer diagnosis. On the one hand, this elucidates how trauma can be understood to constitute a total experience, involving the threat of destruction or loss of the good object (or what Klein (1997) called "the good breast") - the good object being the function of symbolic representation of the world, including cultural meanings and values (Kirshner, 1994). On the other, it corroborates the object relations understanding of conflations and relations between the inner and outer worlds represented by fantasy and reality - or what Bass (2000: 174) aptly characterises as unreal reality. As per my claim in the introduction of this paper, this unreal reality relates to a psychosocial reality.

As an interpretative device, mothering death first articulated the reality of Ella's body hosting a cancerous growth, an invisible and uncontrollable reproduction of cells in her body. Second, it encompassed the unreal sense in which Ella was both fantasising and thinking about mothering death, in the sense of 'nurturing' the cancerous growth to continue its lethal course by refusing treatment. Third, it entailed the biographical and embodied experience of an unplanned pregnancy, and how Ella - in her fantasy - causally related the abortion in her twenties to the fact that she got breast cancer in her fifties. That she never became a mother turned into a harsh causal reasoning - with loss of health, vitality and attractiveness, she would not have something to live for, and therefore she might as well choose to die. Fourth, mothering death expresses a gripping existential and emotional crisis; an entry into which I have called 'a vortex of suffering' (see Figure 2 below). 


\section{The Vortex of Suffering}

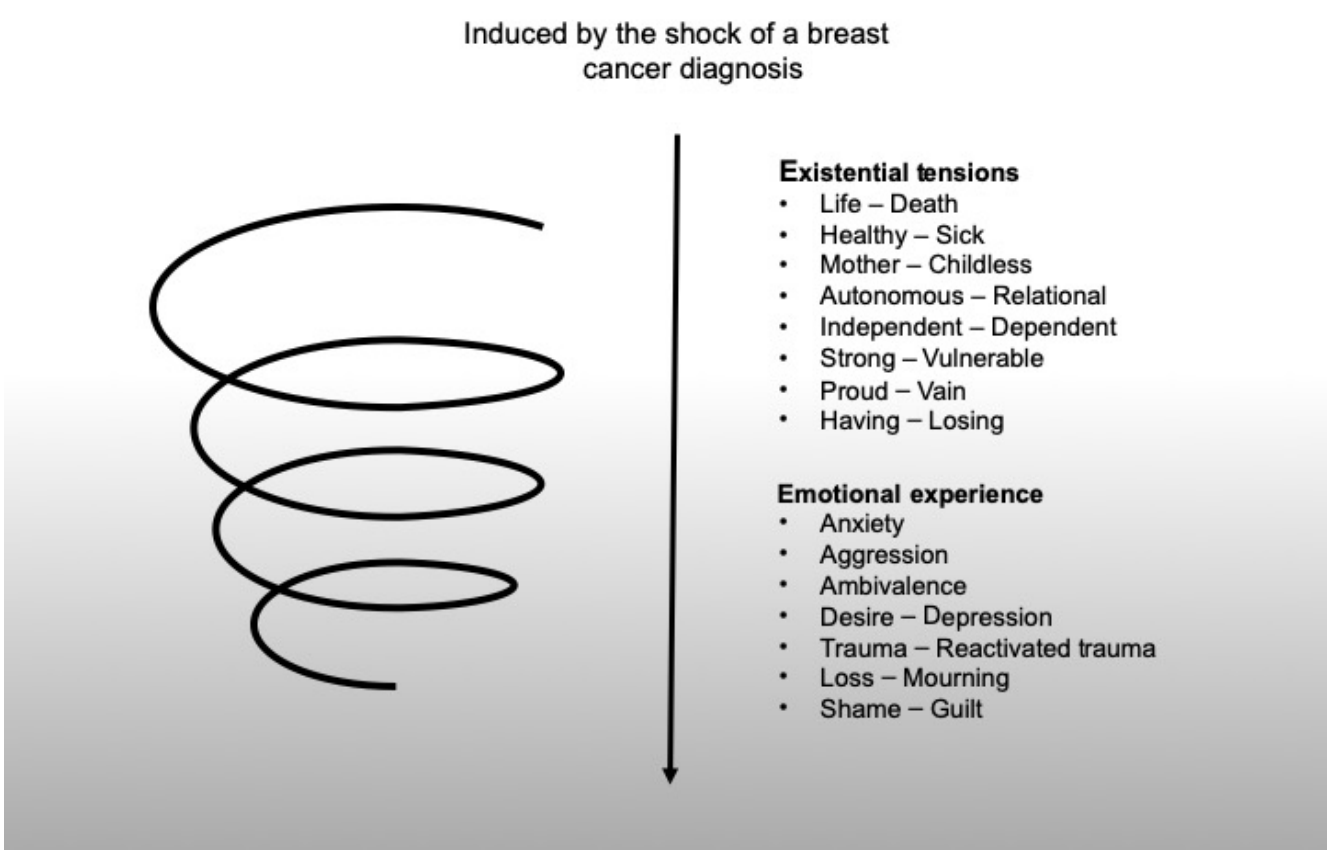

Figure 2: A Vortex of Suffering. This model evokes a gendered version of Vetlesen's (2009, p. 69) ineluctable conditions of life: dependence, existential loneliness, the fragility of relations, and mortality. Hence, "we live our lives in insurmountable vulnerability" and our feelings "bring us into contact with [...] aspects of existence over which we have no control", thereby also revealing "something uncontrollable in ourselves" (Vetlesen, 2009).

\section{Ambivalence about Life from an Object Relations Perspective}

Ella's ambivalence about life and her impulse towards death, can be accounted for psychoanalytically by classical drive theory (Freud, 1920-1922) and object-relations theory (Klein, 1997). Whereas Freud, (1920-1922) identified a basic instinctual conflict between life and death whereby the living organism seeks a return to the inanimate state - Klein developed the theory, seeing "the interaction of the life and death instincts" as governing "the whole of mental life" (1997, p. 245). Klein understood aggression as a powerful agent in emotional life, theorising that the ego projects the death instinct into an object, "giving rise to phantasies of an object which is destroyed and destructive" (Segal, 1991, p. 21). In Ella's fantasy, the destructive object was the cancer 'gestating' within her body, despite her love for the body and her efforts to take care of it. ${ }^{2}$ She could destroy cancer as a bad object by refusing treatment and embracing

\footnotetext{
${ }^{2}$ Unconscious fantasy (or "phantasy") may be a defence against painful reality but may also be a means to reality testing (whether of the 'inner' or 'outer' world) (Spillius et al., 2011). Confoundingly, with regards to this case, the object relations understanding is that its roots are to be found developmentally, emerging from the infant's relation to the breast. I will not go further into a causal exploration here, except to note that the breast, as sexual and reproductive organ and psychosocial symbol, is profoundly charged with meaning (see e.g. Gripsrud et al., 2018).
} 
death, relying on death as a defence against the strong emotions evoked by loss and suffering associated with living with breast cancer. Because she had never become a mother or had dependents, the self (as an object) also became susceptible to destruction.

Larsen (2017) explains defence against anxiety as a psychic necessity for cancer patients. In her interpretation of head and neck cancer patients' narratives, she found evidence of both primitive (splitting, projection) and mature defences (adaptations to reality) (Klein, 1997). Making the shift from schizoid splitting (primitive defence) to depressive position (mature defence) involves developing "the capacity to simultaneously hold the idea of living and dying, [which] may be the most important psychological task in those who become ill, or aged, and who face the end of life" (Rodin \& Zimmermann, 2008, p. 187). As Ella's case illustrates, this is no small endeavour.

From an object relations perspective, the case also illustrates the "conflation of reality as fantasy, past and present" (Segal, 1991, p. 147), characteristic of depressive anxiety. Ella's experience of the time right after diagnosis, where she felt ambivalent about life, may have been too anxiety-provoking to allow her to make out the unruly connections between past and present, and thereby adapt to the reality she was facing as a breast cancer patient. However, depressive anxiety is also what motivates a transition from part-object relations to whole-object relations - from splitting as a necessary defence against anxiety to integration, characteristic of the shift from the paranoid-schizoid to the depressive position - or "the move from fantasy to reality" (Segal, 1991, p. 171). This may be evidenced in the interpretation group's observation of Ella's emotional transition from the first time point (ambivalent about life, self-punishing and self-destructive ideas) to the second (glad and grateful to be alive) - a psychic move from the aggressive-sadistic fantasy of mothering death to 'mothering life', and the return to a more "libidinal engagement with reality" (Segal, 1991, p. 147).

\section{The Deferred Action of Embodied Female Reproduction}

Ella felt shame about her cancer appearance, and guilt (re)emerged in relation to the abortion she had, evoking a vindictive God. In her EW these two feelings oscillated, in the way characteristic of nachträglichkeit or "deferred action" (Laplanche \& Pontalis, 1973, p. 111) as a long-ago embodied experience of pregnancy re-emerged, acquiring a new retrospective significance after the breast cancer diagnosis. In a study on the imaginaries of women who have experienced unwanted pregnancy loss from miscarriage or stillbirth, authors indicate that "the 
idea of the 'dead child' brings with it the idea of the 'dead mother", and that the "real and imaginary construction of motherhood that takes place throughout the pregnancy is $[\ldots]$ interrupted, generating a sensation of loss" (Visintin, Inacarato, \& Vaisbert, 2020, p. 201). Although Ella elected to terminate the pregnancy in her twenties, she may have experienced a similar interruption of imaginary motherhood, which would have started at the point of becoming aware that she was pregnant. A striking idea is that the "dead child", or foetus in Ella's case, can be symbolically and reciprocally returned to a "dead mother", as manifested in a mother's severe depressive reaction to a pregnancy loss. Ella did not say whether she had suffered a depressive reaction after having the abortion. However, decades later, it was this experience that haunted her embodied mind, as she asked herself what wrong she had done to 'deserve' breast cancer and turned to death as a possible and final defence against illness-related suffering and loss.

\section{Exploring the Case's Psychosocial Typologies}

So far, I have been mainly concerned with Ella's inner world, although from a psychosocial understanding this 'inner' world is never severed from the 'world out there'. As Rodin and Simmermann (2008, p. 186) note, "subjective experience is comprised of multiple and shifting self-states and self-organizations generated in social and interpersonal fields". The interpretation group identified Ella's "many battles" after the breast cancer diagnosis. Krüger notes how "[c]onflicts arising at the subjective level might [...] be subjectively suffered, but are always produced in relation with others and therefore never without a sociocultural dimension or free from the contradictions of society at large" (2017, p. 51). In order to explore the sub-text of Ella's case psychosocially, I cannot be satisfied by asking "how did this conflict arise in this individual?" but I must also inquire into a social typology, i.e., by asking "what sort of conflict is this?" (Leithäuser, 2013, para 40). Despite the case's unique characteristics, some of Ella's conflicts may well be accounted for as social typologies. One such typology is of woman as object of the masculine gaze: Ella was somewhat fixated on the idea that other people would look at her and that they would believe certain things about her on the basis of her appearance (for better or worse). Ella did not appear as a stereotypical 'vain woman', but rather she idealised a natural body and made the point that her breasts had been appreciated by the men in her life. The prospect of breast-altering surgery, therefore, not only unsettled Ella's self-image, but her gendered identity as a desirable and naturally beautiful woman. 
A second typology can be identified in that Ella so clearly represents her society and generation: she is a free and independent woman who takes care of things herself, making autonomous decisions, whether it concerns dealing with an unwanted pregnancy or an unwanted cancerous growth. Interestingly, Pines (1993, p. 60) refers to a first pregnancy as:

"a crisis point in the search for a female identity, for it is a point of no return, whether a baby is born at the end of term or the pregnancy ends in abortion or miscarriage. It implies the end of the woman as an independent single unit and the beginning of the unalterable and irrevocable mother-child relationship."

As we know, Ella never completed this transition to motherhood, but must have been confronted with similar concerns evoked by her pregnancy in terms of how she saw herself, her relationships, and her future - indeed her thoughts and feelings about these concerns would have informed her decision to terminate the pregnancy. By the fifties, her identity as an independent woman appears firmly established. Nevertheless, the relationality and dependency associated with social typologies of motherhood pops into her mind when she tries to understand why being a mother offers no choice in whether or not to comply with oncological treatment. Whereas Ella felt 'agency' and 'empowerment' to choose, implying that she was autonomous, she considered her friend's destiny as locked to her dependents because her friend was a mother. In this aspect, Ella's case evokes how the psychosocially defended subject is "constituted from a combination of unique biographical events (in which unconscious dynamics are crucial in determining a person's relation to external reality), and socially shared meanings, interactions and situations" (Hollway \& Jefferson, 2000, p. 104).

Society and culture can effect intrapsychic and interpersonal changes. For example, in the United States, the pervasive pressures of neoliberalism have been accused of creating "ever more individualistic identities that repudiate the vulnerable and needy parts of the self. This, in turn, blocks awareness of the ways in which we are mutually interdependent" (Layton, 2020, p. 178). Layton (2020, pp. 116-117) identifies a change in the psychic structure of middle-class heterosexual American women - a "defensive autonomy", which overlays inner conflicts between nurture and autonomy, reinforced by "the cultural dichotomization of relatedness and autonomy", which "leaves neither pole functioning very well". Although Ella is rooted in a different culture, Norwegian society is not unaffected by neoliberalism (see e.g. Gripsrud, 
Ramvi, \& Ribers, 2020; Ramvi \& Gripsrud, 2017). Ella’s behaviour and narratives could well be interpreted as being imbued with such a "defensive autonomy", to the extreme extent that she fantasied about death as a means to negating vulnerabilities and dependencies activated by breast cancer. However, she had a loving husband. Ella was concerned that she would drive him away, as she transitioned from being a happy, strong, and attractive woman to an unhappy, helpless, emaciated, and despairing hairless apparition. ${ }^{3}$ But when her husband pleaded with her to stay alive and stay in their relationship, the shield of defensive autonomy appears to have lost its power of protection. In the clinic, Ella's defensive autonomy allowed her to be strong and determined in situations with clinicians who wished to cure her disease by taking control over her body. In this context, her behaviour is socially aligned with the outcome of collective battles fought in Norway over women's rights and liberty, including the right to abortion (1975) and, in more recent times, to reconstruction after mastectomy (2012). But despite being enabled by such normative unconscious cultural discourses (Layton, 2020) and personal resources to be a strong-willed and autonomous woman, it was not through 'self-management' but through relations to others (husband, siblings, friends, doctors, and therapists) that Ella regained her footing in life.

A third social typology relates to Ella's mode of self-presentation in her illness narratives. Whereas American culture has produced breast cancer narratives (DeShazer, 2013) apt to rely on a cultural script of "quest stories" (Frank, 1995, p. 166) that thematise omnipotent wishes for triumph over disease and ultimately death, Ella's narratives, emerging from a Norwegian cultural context, are hardly concerned with idealising victory. As such, her case can certainly be said to offer an articulation of situated "non-heroic cancer survivorship" (see Solbrække et al., 2017). Ella's hero quest concerned not an omnipotent denial of death, but finding the courage to live on, even if in suffering.

Following on from my discussion of the case's characteristics and typologies, I now wish to consider some aspects of the psychosocial methodology which allowed her case to be interpreted.

\section{Shared Thinking in a Psychosocial Interpretative Methodology}

The evolution of Ella's case - her breast cancer biography - actualises the relevance of psychosocial approaches that can allow for both depth and branching out from the unconscious intersubjective movements of ideas (Hollway, 2010), both inside and outside the study context.

\footnotetext{
${ }^{3}$ She described her own cancerous gestalt as akin to Gollum from Lord of the Rings.
} 
Such an approach has allowed me to grapple, both alone and together with other researchers, with some seemingly 'irrational' aspects of human experience - whether self-destructive or simply bizarre - in that we are driven by fantasy and affectivity, aspects of which are frequently (or mostly) outside of our own conscious awareness (Meyers, 2015).

My experience of what ensued in the first group interpretation session adheres to Malterud's claim (2001) that when different researchers work together, it allows for access to different layers of the text under investigation, and that different approaches to the same text and subject matter can result in an increased understanding of complex or strange phenomena. In the same vein, Barry et al. (1999) argue that opening up the data in a group is to open up to extended reflexivity - allowing for several interpretations, feelings, fantasies, and working hypotheses to emerge - considered a sign of rigour in qualitative research. In my experience, the strength of depth-hermeneutic interpretation lies in "the group's ability to bring the scenes of the text to life" - an emotionally-engaged way of "thinking and being together" (Gripsrud et al., 2018, p. 647). Such an approach raises the question: how can we understand the relationship between the unconscious of the interpretation group and Ella's unconscious? Psychosocial researchers have theorised notions of a shared unconscious, including the dynamics between expressions of affect and symbolisation processes (Ramvi et al., 2019), which may indeed draw on intra-psychic materials (e.g. specifically related to Ella's case) and socially shared cultural tropes (e.g. such as 'mothering', 'breast' and 'breast cancer'). We can further account for this psychosocially, in the sense that humans are "interdividuals" and that our " "inner world', from before day one, is populated, as it were, by relations to others, and hence is better understood, less as a distinct and separate sphere, than as a fold within the 'outer world"' (Stenner, 2014, p. 207). Wild interpretations that could potentially emerge from one researcher's unconscious reaction are counteracted by the ability of the other group members to check any emerging hypotheses and interpretations against the data material, discarding ideas that cannot be supported by the empirical material.

Still, there can be no doubt that studies of unconscious phenomena constitute an empirical challenge. If the object of a psychosocial inquiry is (a partly) unconscious phenomenon, it is, according to Rustin, "almost by definition" a "non-transparent" object. Indeed, it may well be an object "whose recognition is resisted by their subjects, whether these be individuals, institutions, or societies" (Rustin, 2019, p. 269). In Ogden's view (2008, p. 12), following Bion, it therefore requires at least "two minds to think a person's most disturbing thoughts". For me, this is evident in the scenic voicing of mothering death as a synergistic 
interpretation of Ella's T1 text. Based on the accumulated collective efforts of the group, one person was able to absorb, digest and 'ventriloquise' Ella's "unthought known" (Bollas, 1987) at the time of her EW (linking shame from breast cancer to guilt from the abortion). As the case reveals, group interpretation of data was a powerful device (Hollway, 2008) because it allowed the group to imagine and articulate Ella's most “disturbing thoughts". Its aggregated capacities of human experience and identifications could 'intuit' otherwise untold or unthought aspects of her text "where something that has not yet been symbolised 'presses' into language" (Hollway \& Froggett, 2012, para 13). It is my view that the interpretation group achieved this though the "negative capability" (Bion, 1970, p. 125) to remain in the uncertainty of the puzzle "Ella" and not rush prematurely for conclusions. This achievement may not have been possible, were it not for the reaction of one group member who interrupted the "unbearable interpretation", urging the others to tune in to the strong emotional timbres of Ella's text, rather than defensively intellectualising over it. Following Bion (1962), we could thus say that the first group interpretation session eventually allowed for Ella's raw emotional experience at the point of diagnosis to be contained and metabolised, thereby enabling symbolisation to take place in the second session. This was in a scenic form (mothering death) that allowed the group to synthesise and think about her experience of traumatic suffering, rather than to reject it as 'bizarre', 'incomprehensible' or 'uncompliant' (see also e.g., Hollway \& Froggett 2012).

\section{Closing Remarks}

"I would rather die than lose the breast", was Ella's statement in the breast cancer clinic and my point of departure for this study. In order to investigate it, I relied on a psychosocial interpretative approach that has allowed for an unfolding of the complexities of the embodied, enculturated, and defended woman's breast cancer biography. Different conclusions may be drawn from the case, in recognition of the fact that there will always be much we do not or cannot know (Gripsrud et al., 2018).

At the heart of the interpretation was Ella's two written narratives, which vividly related breast cancer as a "biographical disruption" (Bury, 1982). This traumatic event led her, unconsciously, to search for meaning outside her existing frame. Ella lingered in a cruel and punishing fantasy of mothering death - which can be said to draw, psychosocially, from a cultural script on the self-determined childless woman as a provocation to a normative maternal femininity in which children are assigned to carry the deeper meaning in life. Without children, Ella could choose to die. 
As a breast cancer patient in Norway, Ella was situated within the curative spectrum of a biomedical regime, manifested by a predictable and standardised treatment trajectory provided by the welfare state (Gripsrud et al., 2020). Her resistance to comply with treatment was therefore a mystery to the healthcare personnel, who perceived her as a difficult patient. However, as we have seen, Ella's apparently 'irrational' behaviour and 'failure' to respond as expected to the rationalising medical discourse she encountered at the time of diagnosis and surgery can be accounted for from an object relations perspective - in that maturity is never the attainment of a steady state, but rather is characterised by oscillation with more primitive mental modalities. Crucially, and with some ethical bearing on the current healthcare context, findings point towards her entry into the vortex of suffering as an irrepressible expression of a psychosocial reality, against the backdrop of hope and ideals contained within a psychosocial imaginary that revolves around biomedical cure and reparation.

\section{Acknowledgements}

I am grateful to Ella for taking part in I am not the same, and to Kirsten Lode and Håvard Søiland, with whom I collaborated on this project. Access to data is courtesy of Stavanger University Hospital. I wish to thank the interpretation group - my colleagues in The International Research Group for Psycho-Societal Analysis. My love and gratitude to Wendy Hollway for her reading of an early draft, and to Ellen Ramvi for mothering my entry into Psychosocial Studies. I dedicate this paper to Thomas Leithäuser with much affection - a kindred spirit, without whose sensitive, imaginative and empathetic intellect mothering death would not have seen the light of day.

\section{References}

Arman, M., \& Rehnsfeldt, A. (2003). The hidden suffering among breast cancer patients: a qualitative metasynthesis. Qual Health Res, 13(4), 510-527.

Arroyo, J. M., \& Lopez, M. L. (2011). Psychological problems derived from mastectomy: a qualitative study. Int J Surg Oncol, 2011, 132461. doi:10.1155/2011/132461

Aydin, E., Gulluoglu, B. M., \& Kuscu, K. K. (2012). A Psychoanalytic Study of Subjective Life Experiences of Women with Breast Cancer. Journal of Research Practice, 8(2), 1-15. Retrieved from http://jrp.icaap.org/index.php/jrp/article/view/300/263 
Barry, C. A., Britten, N., Barber, N., Bradley, C., \& Stevenson, F. (1999). Using reflexivity to optimize teamwork in qualitative research. Qual Health Res, 9(1), 26-44. doi:10.1177/104973299129121677

Bass, A. (2000). Difference and Disavowal: The Trauma of Eros. Stanford: Stanford University Press.

Bereswill, M., Morgenroth, C., \& Redman, P. (2010). Alfred Lorenzer and the depthhermeneutic method. Psychoanalysis, Culture \& Society, 15(3), 221-250. doi: $10.1057 /$ pcs.2010.12

Bion, W. R. (1962). Learning from Experience. Nortvale, NJ: Jason Aronson.

Bion, W. R. (1970). Attention and Interpretation. London: Tavistock.

Bollas, C. (1987). The Shadow of the Object: Psychoanalysis and the Unthought Known. London: Free Association Books.

Bury, M. (1982). Chronic illness as biographical disruption. Sociology of Health \& Illness, 4(2), 167-182. doi:10.1111/1467-9566.ep11339939

Cassell, E. J. (2004). The Nature of Suffering and the Goals of Medicine (2nd edition ed.). Oxford: Oxford University Press.

Cheng, T., Causarano, N., Platt, J., Jones, J. M., Hofer, S. O. P., O’Neill, A. C., \& Zhong, T. (2018). Restoring wholeness: Women's embodied experiences in considering postmastectomy delayed breast reconstruction. Cogent Social Sciences, 4(1), 1479478. doi:10.1080/23311886.2018.1479478

Clarke, S., \& Hoggett, P. (2009). Researching Beneath the Surface: Psycho-Social Research Methods in Practice. London: Karnac.

de Boer, M., van der Hulst, R., \& Slatman, J. (2015). The Surprise of a Breast Reconstruction: A Longitudinal Phenomenological Study to Women's Expectations About Reconstructive Surgery. Human Studies, 38(3), 409-430. doi:10.1007/s10746-0159360-6

DeShazer, M. K. (2013). Mammographies: The Cultural Discourses of Breast Cancer Narratives. Ann Arbor: The University of Michigan Press.

Forrester, J. (2017). Thinking in Cases. Cambridge: Polity Press.

Frank, A. W. (1995). The Wounded Storyteller: Body, Illness, and Ethics. Chicago: The University of Chicago Press.

Freud, S. (1920-1922). Beyond the Pleasure Principle; Group Psychology; And, Other Works (Vol. 18). London: Hogarth Press. 
Froggett, L., \& Briggs, S. (2012). Practice-Near and Practice-Distant Methods in Human Services Research. Journal of Research Practice, 8(2). Retrieved from http://jrp.icaap.org/index.php/jrp/article/view/318/276

Geertz, C. (1973). The Interpretation of Cultures: Selected Essays. New York: Basic Books.

Gray, A. (2003). Research Practice for Cultural Studies: Ethnographic Methods and Lived Cultures. London: Sage.

Greco, C. (2015). Shining a light on the grey zones of gender construction: breast surgery in France and Italy. Journal of Gender Studies. doi:10.1080/09589236.2014.987653

Gripsrud, B. H. (2006). Spectacular Breasts: Mapping Our Historical and Contemporary Cultural Fascination with the Breast. (PhD Monograph). University of Leeds, Leeds.

Gripsrud, B. H. (2008). The Cultural History of the Breast. In V. Pitts (Ed.), A Cultural Encyclopedia of the Body (Vol. 1, pp. 31-44). Westport: Greenwood Publishing.

Gripsrud, B. H., Brassil, K. J., Summers, B., Søiland, H., Kronowitz, S., \& Lode, K. (2016). Capturing the Experience: Reflections of Women With Breast Cancer Engaged in an Expressive Writing Intervention. Cancer Nursing, 39(4), 51-60. doi: $10.1097 /$ ncc.0000000000000300

Gripsrud, B. H., Mellon, K., \& Ramvi, E. (2018). Depth-hermeneutics: a psychosocial approach to facilitate teachers' reflective practice? Reflective Practice, 19(5), 638-652. doi:10.1080/14623943.2018.1538955

Gripsrud, B. H., Ramvi, E., Froggett, L., Hellstrand, I., \& Manley, J. (2018). Psychosocial and Symbolic Dimensions of the Breast Explored through a Visual Matrix. NORA - Nordic Journal of Feminist and Gender Research, 1-20. doi:10.1080/08038740.2018.1482958

Gripsrud, B. H., Ramvi, E., \& Ribers, B. (2020). Couldn't care less? A psychosocial analysis of contemporary cancer care policy as a case of borderline welfare. Journal of Psychosocial Studies. doi:https://doi.org/10.1332/147867320X15985348674895

Gripsrud, B. H., Søiland, H., \& Lode, K. (2014). Ekspressiv skriving som egenterapeutisk verktøy ett år etter brystkreftdiagnosen - resultater fra en norsk pilostudie [Expressive writing as a self-therapeutic tool one year after the breast cancer diagnosis - results from a pilot study]. Nordisk Tidsskrift for Helseforskning(2), 45-61.

Gullestad, S. E., \& Killingmo, B. (2013). Underteksten. Psykoanalytisk terapi i praksis [The Sub-text: Psychoanalytic Therapy in Practice]. Oslo: Universitetsforlaget.

Hammersley, M., \& Atkinson, P. (1983). Ethnography: Principles in Practice. London: Tavistock.

Hollway, W. (2008). The importance of relational thinking in the practice of psycho-social research: ontology, epistemology, methodology, and ethics. In S. Clarke, H. Hahn, \& P. Hoggett (Eds.), Object Relations and Social Relations: The Implication of the Relational Turn in Psychoanalysis (pp. 137-161). London: Karnac. 
Hollway, W. (2009). Applying the 'Experience-Near' Principle To Research:

Psychoanalytically Informed Methods. Journal of Social Work Practice, 23(4), 461474. doi:10.1080/02650530903375025

Hollway, W. (2010). Relationality: The intersubjective foundations of identity. In M. Wetherell \& C. Mohanty (Eds.), Sage Handbook of Identities (pp. 216-232). London: Sage.

Hollway, W., \& Froggett, L. (2012). Researching in-between subjective experience and reality. Forum Qualitative Sozialforschung / Forum: Qualitative Social Research, 13(3), Article 13. Retrieved from http://www.qualitativeresearch.net/index.php/fqs/article/view/1899/3428

Hollway, W., \& Jefferson, T. (2000). Doing Qualitative Research Differently: Free Association, Narrative and the Interview Method. London: Sage.

Hollway, W., \& Jefferson, T. (2001). Free association, narrative analysis and the defended subject: The case of Ivy. Narrative Inquiry, 11(1), 103-122.

Hollway, W., \& Volmerg, B. (2010). Interpretation group method in the Dubrovnik tradition. Manual.

Kirshner, L. A. (1994). Trauma, the good object, and the symbolic: a theoretical integration. Int J Psychoanal, 75 ( Pt 2), 235-242.

Klein, M. (1997). Envy and Gratitude and Other Works 1946-1963. London: Vintage Books.

Kleinmann, A. (1988). The Illness Narratives: Suffering, Healing and the Human Condition. New York: Basic Books.

Krüger, S. (2017). Dropping depth hermeneutics into Psychosocial Studies - A Lorenzarian perspective. The Journal of Psycho-social Studies, 10(1), 47-66.

Langellier, K. M., \& Sullivan, C. F. (1998). Breast talk in breast cancer narratives. Qual Health Res, 8(1), 76-94. Retrieved from http://www.ncbi.nlm.nih.gov/pubmed/10558328

Laplanche, J., \& Pontalis, J.-B. (1973). The Language of Psychoanalysis. London: Karnac Books.

Larsen, B. N. (2017). Ingen plads til angst. Patienters erfaring fra den diagnostiske periode af krceftforløb for hoved-og halskrceft. (Ph.d.). Roskilde Universitet, Roskilde.

Layton, L. (2020). Toward a social psychoanalysis: Culture, character, and normative unconscious processes. London: Routledge.

Leithäuser, T. (2013). Psychoanalysis, socialization and society - The psychoanalytical thought and Interpretation of Alfred Lorenzer. Forum Qualitative Sozialforschung / Forum: Qualitative Social Research, 13(3), 56-70. Retrieved from http://www.qualitative-research.net/index.php/fqs/article/view/1907 
Lévi-Strauss, C. (1966). The Savage Mind. Chicago: The University of Chicago Press.

Levine, S. K. (2009). Trauma, Tragedy, Therapy: The Arts and Human Suffering. London: Jessica Kingsley Publishers.

Lorde, A. (1980). The Cancer Journals (Second edition ed.). San Francisco: Aunt Lute Books.

Lothane, H. Z. (2018). Free Association as the Foundation of the Psychoanalytic Method and Psychoanalysis as a Historical Science. Psychoanalytic Inquiry, 38(6), 416-434. doi:10.1080/07351690.2018.1480225

Malterud, K. (2001). Qualitative research: standards, challenges, and guidelines. Lancet, 358(9280), 483-488. doi:10.1016/s0140-6736(01)05627-6

Meyers, W. R. (2015). Social Science Methods for Psychodynamic Inquiry: The Unconscous and the World Scene. London: Palgrave Macmillan.

Ogden, T. H. (2008). Bion's four principles of mental functioning. Fort Da, 14B, 11-35.

Pennebaker, J. W. (1997). Opening Up: The Healing Power of Expressing Emotions. New York: The Guilford Press.

Pines, D. (1993). A woman's unconscious use of her body. New Haven: Yale University Press.

Ramvi, E. (2015). I am only a nurse: a biographical narrative study of a nurse's selfunderstanding and its implications for practice. BMC Nursing, 14(23), 1-9.

Ramvi, E., \& Gripsrud, B. H. (2017). Silence about encounters with dying among healthcare professionals in a society that 'de-tabooises' death. International Practice Development Journal, 7. doi:https://doi.org/10.19043/ipdj.7SP.009

Ramvi, E., Manley, J., Froggett, L., Liveng, A., Lading, A., Hollway, W., \& Gripsrud, B. H. (2019). The visual matrix method in a study of death and dying: Methodological reflections. Psychoanalysis, Culture \& Society, 24(1), 31-52. doi:10.1057/s41282-0180095-y

Rodin, G., \& Zimmermann, C. (2008). Psychoanalytic reflections on mortality: a reconsideration. J Am Acad Psychoanal Dyn Psychiatry, 36(1), 181-196. doi:10.1521/jaap.2008.36.1.181

Rustin, M. (2019). Researching the Unconscious: Principles of Psychoanalytic Method. London: Routledge.

Segal, H. (1991). Dream, Phantasy and Art (2nd edition 2004 ed.). Hove: Brunner-Routledge.

Solbrække, K. N., Søiland, H., Lode, K., \& Gripsrud, B. H. (2017). Our genes, our selves: hereditary breast cancer and biological citizenship in Norway. Medicine, Health Care and Philosophy, 20(1), 89-103. doi:10.1007/s11019-016-9737-y 
Spillius, E.B., Milton, J., Garvey, P., Couve, C. \& Steiner, D. (2011) The New Dictionary of Kleinian Thought. London: Routledge

Stake, R. (1995). The Art of Case Study Research. Thousand Oakes: Sage.

Stenner, P. (2014). Psychosocial: qu'est-ce que c'est? Journal of Psycho-Social Studies, 8(1), 205-216.

Vetlesen, A. J. (2009). A Philosophy of Pain. London: Reaktion Books.

Visintin, C., Inacarato, G., \& Vaisbert, T. (2020). Imaginaries of women who experienced a pregnancy loss. Estilos da Clinica, 25, 193-209. doi:10.11606/issn.1981-1624.v25i2

Wengraf, T. (2001). Qualitative Research Interviewing. London: Sage.

Yalom, M. (1998). A History of the Breast. London: Pandora.

\begin{abstract}
About the Author
Birgitta Haga Gripsrud is an Associate Professor in the Department of Caring and Ethics at the University of Stavanger, Norway. She holds a PhD in Cultural Studies (University of Leeds, 2006). Gripsrud's research interests are in psychosocial studies of enculturated and embodied experience, and of professional relational practice, as well as ethics of care. She is concerned with a 're-humanisation' of health and medicine in the face of a neoliberal performance culture, which e.g. refutes awareness of complexity and suffering as inescapable dimensions of life experience.
\end{abstract}

